\title{
THE USE OF PODCASTS AND VIDEOCASTS BY TERTIARY ACCOUNTING STUDENTS IN DISTANCE EDUCATION
}

\author{
L. Wentzel* \\ e-mail:wentzmsi@unisa.ac.za

\section{K. de Hart*} \\ e-mail: dhartkı@unisa.ac.za \\ *Department of Taxation \\ University of South Africa \\ Pretoria, South Africa
}

\section{ABSTRACT}

Podcasts and videocasts are increasingly used in education, as they provide additional flexible learning resources to students. Research on the educational use and design of videocasts used by students in a distance education environment is, however, limited. In light of the need to ascertain how best to design videocasts, this article reports on distance students' perceptions of using this technological innovation as part of teaching support provided by educators. The research was conducted by means of a survey and it investigated how videocasts were used by undergraduate students in a taxation module. The research also investigated the usefulness of videocasts to students in mastering the extensive content and complex principles. The results from this study found that students generally access the videocasts from home on a computer/laptop while working through or after reading the study unit. Most students reject the mobile aspect of videocasting and prefer to maintain their traditional study habits by watching each videocast at least once (or more than once for more difficult topics) during their focused study time. The majority of students perceive videocasting as having value, as this initiative provides them with additional support and helps them to understand the content more easily. It is evident that the use of videocasts as an additional learning tool in taxation distance education courses can enhance the learning experience of accounting students and it is a viable way of communicating content to and documenting processes for students to enable them to study more effectively.

Keywords: Podcast, videocast, distance education, learning support, technology, accounting

\section{INTRODUCTION}

Digital technologies, including the Internet, have permeated most aspects of our lives, from communication, banking, shopping online and much in between (Conole 2013, 3). In more digitally sophisticated and innovative contexts, there is an expectation of, and driver for, certain levels of connectivity (Conole 2013, 4). In South Africa, which is a middle income economy, 
characterised by high inequality, this is not always the case in all geographic areas. In an attempt to address the unequal digital divide, the government continues to roll out $\mathrm{Wi}-\mathrm{Fi}$ in public areas and reduce the cost of devices and data. As a central component of life, education has not been left untouched by these advances and many of today's learners, who are often referred to as "digital natives" (Prensky 2001, 1), are "technologically immersed" and as such, they learn in a different, more socio-technological manner through their engagements with learning contexts afforded by technology. Technology has opened up education beyond the traditional residential options to many different online/distance initiatives that have additionally advanced the massification of education (Altbach, Reisberg and Rumbley 2009, vi). In 1983, Moore provided seminal and theoretical impetus to such distance (and concomitantly the technology that enables distance education and massification) within the paradigm shifting concept of "transactional distance".

There is now a distance between learner and teacher which is not merely geographic, but educational and psychological as well. It is a distance in the relationship of the two partners in the educational enterprise (Moore 1983, 55).

Beldarrain $(2006,139)$, in turn, drills this concept down even to the level of the tools of the transaction that happens over the "distance". He explores how technology tools advance not only the delivery of content for learning, but also gives a sense of the proximate presence of fellow learners, facilitators and even collaborative content to advance distance education (DE). Saba, who has been described as one of the most sophisticated theorists and highly regarded scholars in the field of distance education (Moore 2013, 1; Moore and Anderson 2003, xiv), locates distance education elements such as these tools and transactions within pragmatism, yet also expansively within systems philosophy (Saba 2013, 53; Moore and Kearsley 2012, 209).

In the light of the trajectory from transactional distance, tools of the transaction - and the broader role of technology thereto, this article considers two teaching-learning tools within a mega distance education university (Daniel 1996, 29). We consider pod- and video-casts and how these "distance" tools are positioned within the systems view, as highlighted by (Saba 2012, 31)

\section{Systems and disciplinary context}

Many students register for distance education not through choice but through not having access to face-to-face offerings, because of cost, poor performance, having to work at the same time, or lack of space in traditional institutions. These are systemic realities within an emerging economy context (Altbach 2012, 10). Developments in technology and the Internet have, 
however, increased access to education, especially distance education. Technological interventions may also assist students in understanding crucial and complicated content within disciplines. For subjects, such as taxation, delving into concepts and principles is complex and explanations become lengthy. For example, consider the processes and arguments that support a tax calculation or the application of taxation legislation to applied problems, using text (which remains the main method in distance education in South Africa). This means of teaching and learning is extremely cumbersome. Moore's notion of transactional distance $(1983,55)$, therefore, has to be mediated through more vivid teaching and learning strategies. The use thus of tools such as podcasts and videocasts in taxation distance education courses is a viable way of communicating content to, and documenting processes for, students (Beldarrain 2006, 139).

\section{Technology tools for DE}

Podcasting is not new in the sense that audio (radio and cassette) has been used for many years in distance education (Edirisingha, Hawkridge and Fothergill 2009, 1; Van Zanten 2008, 1066). However, the delivery of audio with the affordance of the Internet makes podcasting particularly appealing. A podcast is an audio clip that is distributed over the Internet for playback on a portable media device or personal computer (Kay 2012, 821). The term "podcast" is a combination of the words "iPod" (a media player that can store and play audio and video files) and "broadcast". With the increase in Internet capability and advances in software, video can also be added to the audio and delivered to students. The term "videocast" is used to describe video files and is similar to a podcast, but with added visual elements. Educational podcasts are usually distributed on course management systems and public video websites such as YouTube (Gattis 2008, 1). For purposes of this article, the term "videocast" will include podcasts as well.

The use of podcasting has grown exponentially in higher education (Baker et al. 2008, 49; Dale 2007, 49), however, academics still need to find the best way of using videocasting as part of their offerings (Baker et al. 2008, 49) and to enhance the DE teaching and learning system both pragmatically and summatively (Saba 2005, 262). Research on the educational use of technologies like videocasting is limited (Scutter et al. 2010, 181), as is research on the design of videocasts (Dennen and Myers 2010,44). In light of the need to ascertain how best to design videocasts, this study focuses on how undergraduate students in a taxation module use podcasts and videocasts provided to them as an additional DE and transactional learning resource.

\section{LITERATURE REVIEW}

Distance education originated from the need to provide education to students who would not 
otherwise be able to participate (Beldarrain 2006, 139). This resulted in an education system where students and teachers were separated by time and distance (Keegan 2013, 9). Saba (2005, 266) argues that it is this very system that may be adapted pragmatically for learning and teaching evolution. Advances and developments in technology have played a major role in decreasing this distance as well as offering alternative delivery options (Beldarrain 2006, 140). Similar advances in conceptualising DE have opened up the systems and worldviews to consider DE within a social science perspective through empirical work that demonstrates transactional distance (Saba and Shearer 2018, 10). Apart from the separation aspect of distance education, students learning at a distance and registered for the same module, come from diverse backgrounds, with varied needs, different learning styles and differing academic competencies (Stöter et al. 2014, 422). The skills differences or literacies of the students pose a challenge to teachers in terms of to how to approach the facilitation of teaching and learning. Technologies like podcasts and videocasts can assist in this regard. These might be differentially developed, in prior consultation with the learners, for a more dynamic response to learner needs, as suggested by (Saba 2011, 15) in his pragmatic review of DE within a more open-ended systems approach.

Additionally, other literature and studies highlight a number of reasons as to why videocasts should be considered as a way of transferring content and facilitating knowledge acquisition. Reasons include the fact that students are becoming more immersed in technology, the use of videocasts fosters interaction (Berge 2013, 379; Beldarrain 2006, 141), they accommodate the different learning styles of students (Bolliger, Supanakorn and Boggs 2010, 715; Cebeci and Tekdal 2006, 49; Dale 2007, 51; Fernandez, Simo and Sallan 2009, 386; Gattis 2008, 1; Scutter et al. 2010, 181), they are a good support mechanism (Dale 2007, 51), they allow flexibility for students (Bolliger et al. 2010, 715; Dale 2007, 51; Beldarrain 2006, 140), they can increase the student's interest in the content (Baker et al. 2008, 49; Chan and McLoughlin 2006, 112), and it keeps them focused on the course (Edirisingha, Salmon and Fothergill 2007, 130). Students have indicated that the benefit of replaying a videocast as many times as needed was of major assistance in mastering the module content (Tynan and Colbran 2006, 831) and more so for students whose first language is not English (Sutton-Brady et al. 2009, 227). Several other studies (Dale 2007, 51; Evans 2008, 496) have also reported that podcasting can be an effective learning tool, especially when the subject content is complicated. In a research survey carried out by Meade, Bowskill and Lymn (2009, 85), students indicated that podcasts improved their understanding of the subject and this perception was confirmed by the marks obtained by these students. Students also enjoy the mix of media, so that the learning process is no longer limited to reading the module content. The learning process is thus 
transformed to a more interesting experience for students (Sutton-Brady et al. 2009, 219). At an aggregated level, these rationales for such technology tools contribute to the central contention as held by (Saba 2005, 265). It is in these more creative, autonomous (yet, within a dynamic structure) methods that the distance of the teaching and learning transaction may be mitigated. These methods also herald and tap into more "cybernetic technologies" that advance systemic treatment of the complexity of learning in DE (Saba 2005, 265).

It should be noted, however, that many of these studies have been carried out in terms of podcasting usage for face-to-face students and not for distance students. Some studies that have focused on distance students, show that podcasts enhance the distance learning experience through variety, as an important supplementary support to the traditional study materials (Lee and Chan 2007, 87) and they allow distance students to be flexible as to when they learn (Van Zanten 2008, 1068). Podcasts also reduce the feeling of isolation that distance students often experience (Beldarrain 2006, 150).

Criticisms of podcasting refer to the fact that the recording of lectures increases absenteeism (Khechine, Lakhal, and Pascot 2009, 590; Meade, Bowskill and Lymn 2009, 75; Scutter et al. 2010, 187); this however is not applicable to distance education. Another criticism is that podcasting encourages passive learning (Elliot, King and Scutter 2009, 31). In this regard, Evans (2008, 496) suggests that videocasts should be designed to "help learners assimilate the material and construct their own understanding”. Viewing videocasts and listening to podcasts may engage students more especially if they are designed in such a manner so as to actively involve students with the learning materials. This study investigates students' perceptions of using podcasts and videocasts as part of learning materials.

\section{METHODOLOGY}

The investigation into the use of videocasts by second-year taxation students took the form of a quantitative research design by utilising a survey as the research method. Ethical clearance was obtained from the Unisa Senate Research and Innovation and Higher Degrees Committee before the research commenced. The survey was used to answer two research questions:

1. How do students use videocasts?

2. How do videocasts support learning?

\section{Context}

With specific reference to its magnitude and influence, the University of South Africa (Unisa) is a mega open distance learning (ODL) university offering study opportunities to more than 
350000 students around the world. Qualifications from certificates to degrees (up to doctorate level) are offered. During the 2018 academic year, 381483 registered students were studying towards 891 formal qualifications. Unisa is South Africa's most productive university, accounting for 12,8 per cent of all degrees conferred by the country's 26 universities and universities of technology (University of South Africa 2020). Unisa is busy transforming from a predominantly paper-based correspondence university to one that delivers learning material electronically on a learning management system (De Hart, Chetty and Archer 2015, 25).

\section{Participants}

The study was conducted with second-year taxation students registered during the second semester of 2015 at Unisa. TAX2601 students (n=3 050 admitted, 2454 wrote exam) were provided with 5 podcasts and 7 videocasts on the LMS as "additional resources". A systematic randomly selected statistical sample (323 students) was identified, of which 316 students agreed to take part in the survey. This number of responses is too small to generalise the results, but valuable insight is still gained from the outcome of this study. The survey was applied using computer-aided telephone interviews. The interviews were carried out during the end of the semester by a trained and experienced team of telephone interviewers employed by Unisa's Bureau for Market Research.

\section{Demographics of respondents}

The majority (84.8\%) of respondents are in the age groups 22 to 30 and 31 to $40(54.7 \%$ and $30.1 \%$ respectively). The remaining 15.2 per cent represent all the other age groups. A total of 64.2 per cent of respondents are female and 35.8 per cent are males. The respondents indicated that they are part of the following ethnic groups: Black (72.8\%), White (15.2\%), Indian $(9.8 \%)$ and Coloured $(2.2 \%)$. A total of 238 respondents $(n=316,75.3 \%)$ were attempting this module for the first time, while $78(24.7 \%)$ were repeat students. Most respondents $(84.5 \%)$ were studying part-time.

\section{Data collection and analysis}

The development and refinement of an appropriate survey instrument for Unisa's context was guided by relevant literature. The survey focused on how students made use of the videocasts and how the videocasts supported their learning and mitigated the proximity barriers. All surveys were anonymous and no students could be identified based on their responses.

Qualtrics $^{\mathrm{TM}}$ was used to administer all surveys and the interviewers captured the respondents' answers in full. In very few cases, the telephone call was "dropped" and the 
interviewer therefore could only capture the respondent's answers up to that point. It also occurred that some respondents answered the first part of the survey, but opted to exit the survey at some point, thereby not completing the full survey. Some students also elected not to answer certain questions. For these reasons, the sample size (n) differs for each question discussed in the results section. The researchers elected to include all responses nonetheless, as the feedback received from incomplete surveys still provided valuable input.

Data analysis was conducted using SPSS version 23. Descriptive and inferential statistical analyses were performed. Descriptive statistics are described using tables and charts. An exploratory factor analysis was conducted on a question which tested the opinions of the participants, using Principal Axis Factoring to determine the dimensionality of the set of experience of use opinions. The Kaiser-Meyer-Olkin Measure of Sampling Adequacy was 0.872, which is above the recommended threshold of 0.5 and the Bartlett's Test of Sphericity was significant $(p<0.001)$ for the ten opinions relating to the experience of use, therefore indicating that a factor analysis was appropriate. The analysis identified two factors based on the eigenvalue criterion (eigenvalue greater than 1) and the factors explain 51.6 per cent of the variance. The two identified factors were labelled as attention and usefulness.

The internal consistency (reliability) using the Cronbach Alpha coefficient is 0.713 and 0.743 for attention and usefulness respectively, which are both above the recommended threshold of 0.7 , and therefore the reliability is considered satisfactory. Factor scores were calculated as the mean value of the items included in each factor. The mean and standard values were 3.9 and 0.68 for attention and 3.7 and 0.73 for usefulness. Inferential analysis was performed to determine significant differences, as well as associations, between several variables. Both parametric and non-parametric tests, the Mann-Whitney, Kruskal-Wallis and the t-test, were conducted.

\section{RESULTS AND DISCUSSION}

\section{Use of videocasts}

In order to ascertain the use of the videocasts, the participants were asked whether they had watched any of the videocasts. Those who did not, were asked for their reason for not doing so.

\section{Did you listen to any of the podcasts or watch any of the vodcasts on myUnisa?}

While 127 ( $\mathrm{n}=316,40.2 \%$ ) respondents watched or listened to the additional resources, 189 $(59.8 \%)$ respondents did not. The reported lack of use of videocasts is disconcerting and needs to be explored. The lecturers believed that the videocasts were valuable to the students' 
understanding of concepts and especially saving them time in understanding complex issues.

\section{Why did you not make use of the resources?}

The respondents were given five preselected answers as well as an "other" option, with reasons. Respondents were able to select more than one option.

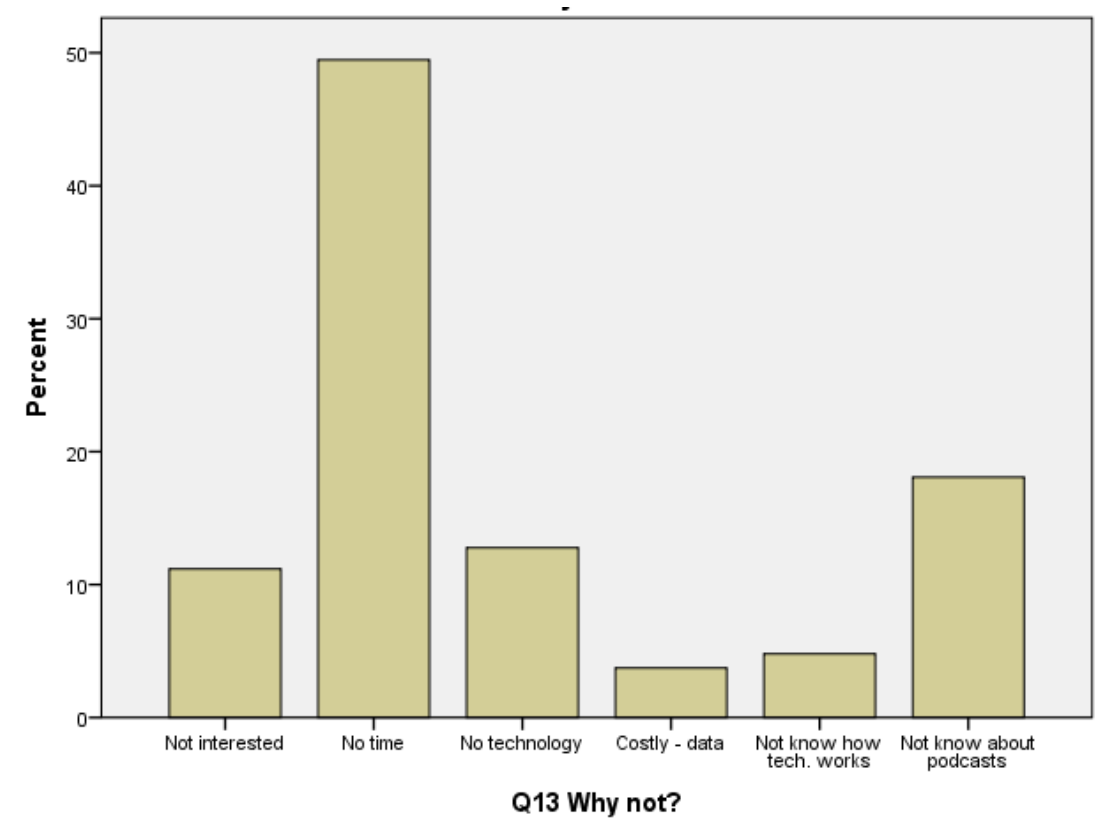

Graph 1: Reasons why students did not download and watch the videocasts

From the results, it can be seen that lack of time was the leading reason as to why students did not engage with the videocasts. This is in line with the findings reported by Sutton-Brady et al. (2009). Their results show that students are under significant pressure to keep up with current workloads; downloading and viewing videocasts are seen as time consuming, although students think that the concept is a good idea. Students are hesitant to integrate new skills to their traditional study process while the course content is very intensive. Should more efforts be made consciously to integrate videocasts, along the lines of the more complex systems learning model, as suggested by (Saba 2005, 265), this constraint might well be minimised. When DE is formulated within a social system as opposed to physical science (Saba 2005, 270), learners are better able to integrate different methods of learning into the overall sense-making of more holistic learning within such computer mediated discourses (Stefanski, Leitze and Fife-Demski 2018, 46).

According to the Technology Acceptance Model (Davis 1993, 476), a user's acceptance of a specific technology is determined by the perceived usefulness and the perceived ease of use. This results in a user only investing effort into using a new technology if they are rewarded 
by its usefulness. By implication, the user will not attempt to master the technology if they do not yet know what the benefit will be. The current study has highlighted that lecturers will need to effectively communicate how the videocasts will assist the students in mastering the content and explain how much time it will consume. If students understand that the time investment is not significant and worth the benefit, they may endeavour to utilise this addition tool during their study programme.

There are a number of possible reasons for time being an issue in this study. Most of the respondents indicated that they were studying part-time. Distance students often register for more courses than they can manage in terms of working through the content, assignments and examples. The videocasts in this study were additional resources, and therefore seen as additional to the DE system and not integral to it and, as such, were perceived to be added to the workload and time requirements of students. The second most prevalent reason that respondents gave for not watching the videocasts was that they did not know that the videocasts existed. Once again this is disconcerting as students were alerted to the availability of videocasts by announcements on their LMS (which are e-mailed to their Unisa myLife e-mail), as well as two text messages to their cell phones (mobiles) during the semester. It is likely that many students do not activate or access their myLife e-mail account, which means that they miss out on all communication from the lecturers. If the students are not aware of videocasts on the LMS, it could mean that they do not know how to use the LMS effectively and are missing out on other support mechanisms like the discussion forums and e-tutors, which is a concern to the academics as much of the distance student's support is derived from the LMS.

Some respondents also indicated that they do not have the technology $(12.8 \%, n=127)$. This result is in line with a survey on Unisa student ICT sophistication carried out by Unisa in the latter half of 2014 (Liebenberg and Van Zyl 2015). This survey indicated that 80 per cent of students have access to a laptop and 71 per cent have access to a desktop computer. These constraints therefore exclude the students from the teaching and learning system, making DE through technology into a so-called killer assumption.

Interestingly, the costs involved in downloading the videocasts were of least concern for many of the respondents, as it is often reported that data costs in South Africa are among the highest in the world (Smillie 2016, Internet article) and this means that learners need to be willing to make an investment if they are serious about obtaining additional support in mastering the subject content. Unisa has been proactive in this regard and has negotiated data deals for its students with the major service providers (MyBroadband 2013, Internet article).

The remainder of questions in the survey were directed to participants who had watched the videocasts. These dealt with the participant's videocast experience, their study habits as 
well as the perceived usefulness of the videocasts.

\section{Videocast experience}

In terms of these questions, participants were assessed on how many times they accessed videocasts, on what device they watched them, problems encountered in accessing videocasts and how such challenges were resolved. The respondents referred to in this section refer only to those who made use of the videocasts.

\section{Where did you mostly access or download the videocasts?}

Respondents reported that they mostly accessed the videocasts from home $(65.9 \%, \mathrm{n}=123)$ and the remainder gained access from work, a Unisa centre or an Internet café. For distance students, this response is expected. A total of 84.5 per cent of the respondents study part-time and these students might not be able to access the videocasts during working hours. However, not everyone has Internet access at home and therefore it is expected that other facilities which provide access to the Internet would also be used.

\section{On what device did you mostly download and/or watch the videocast?}

The majority of respondents watched the videocasts on a computer or laptop $(80 \%, n=125)$. Cell phones (13.6\%) and iPods/mp3 players (6.4\%) were also used. These responses correspond with the Unisa ICT survey (Liebenberg and Van Zyl 2015, 9) which reported that the most common devices used by students to access the Internet are personal computers and laptops, although mobile devices are becoming equally popular.

The literature shows that one of the benefits of videocasts is that they can be viewed any time and any place (Lee and Chan 2007, 90). However, the results from this study revealed that most respondents download the videocasts on their computer and watched it at home. This finding is supported by other studies (Meade, Bowskill and Lymn 2009, 76; Sutton-Brady et al. 2009, 223; Tynan and Colbran 2006, 829) where a significant number of respondents had access to an $\mathrm{iPod} / \mathrm{MP} 3$ player, but most of them used their computer to listen to the videocasts.

It seems that students reject the mobile aspect of videocasting and prefer to maintain their traditional study habits, perhaps suggesting that students are inhibited by DE still as rigid and not conducive to more creative autonomy, as suggested within the transactional distance model (Moore 1983, 55). Comments from Sutton-Brady et al.'s $(2009,223)$ focus groups reveal that students prefer to listen to the podcasts when they have access to their other learning-related resources and when they are able to concentrate with minimal distractions. This is especially the case with students who study in a language that differs from their mother tongue. Although 
students realise the value of using mobile devices, such as cell phones, to access course documents and upload course content (Gikas and Grant 2013, 19; Traxler 2010, 133), they prefer to use their cell phones for social networking, texting and listening to music, rather than for educational purposes (Taleb and Sohrabi 2012, 1108; Wang, Wu and Wang 2009, 93). Students are also weary to use cell phones for academic activities due to the technical limitations of these devices, such as small screen sizes with poor resolution, slow download speed and limited memory (Elias 2011, 145; Huang et al. 2008, 1207; Lowenthal 2010, 197).

\section{What problems did you encounter by accessing the videocasts?}

It is note-worthy that only 11.2 per cent of the respondents faced challenges while downloading the videocasts. Technical problems were experienced by 8.8 per cent of the respondents, while 1.6 per cent did not have any Internet access and 0.8 per cent could not afford to download all the videocast resources. This is in line with other studies (Scutter et al. 2010, 188; Tynan and Colbran 2006, 831) where very little problems were encountered by the respondents, and the problems were resolved fairly easily. This result is also in line with the Unisa ICT survey (Liebenberg and Van Zyl 2015, 19), where the students indicated that they were comfortable with aspects of the Internet, for example an Internet browser and search engines. The Unisa survey did not specifically request students to evaluate their skills in downloading documents from the Internet, but in the same vein, the majority $(87 \%)$ of students evaluated their myUnisa (LMS) skills as good.

\section{Study habits}

Students will use the videocasts differently from each other, based on their unique learning style. As this research is an exploration into how students make use of the videocasts to support their studies, the following questions attempted to ascertain the manner in which the videocasts were used by participants:

\section{When (during the study period) did you use the videocasts?}

Respondents were given four preselected options and were asked to rank them from most used to least used based on their general use of the videocasts. The four options were as follows: Before you read the study unit, while working through the study unit, after reading the study unit and as revision before the exam. The results show that students mostly use the videocasts after reading the study unit $(31.7 \%, \mathrm{n}=121)$ and while working through the study unit $(29.2 \%)$, while only some use it as revision before the exam (20.8\%) and before they read the study unit $(18.3 \%)$. This is an important indicator to the academics who create the videocasts, as it will 
influence the design and content of the videocasts to enhance the usefulness of this resource. Since the responses show that this additional support is used less during revision or before working through the unit, it follows that ample detail must be covered in the recording, since the student is not necessarily familiar with the technical content or proficient in taxation calculations when the videocast is viewed. Many students view the videocasts after initially working through the study unit, which also shows that the content of the videocasts should not provide too much basic or introductory information on the topic and rather focus on more complex issues within the unit.

\section{When (during the day) did you mostly listen to or watch the videocasts?}

Most students $(79.4 \%, \mathrm{n}=126)$ used the videocasts during their study time, whilst some students (16.7\%) viewed the videocasts during their lunch break at work. Only 2.4 per cent of the respondents listened to the videocasts while commuting, which is surprising given the fact that one of the characteristics of videocasts is that it is portable when listened to on an iPod/MP3 player, as well as a cell phone. This is closely linked to the device students mostly used to download and/or watch the videocasts, where only 20 per cent of the students used a mobile device. This explains the small percentage of students using the videocasts while commuting, as students prefer to download and access the videocasts on computers. This response is also an indication that students are more likely to use the videocasts with focused attention during their study time, than listening to it at other times when distractions are possible.

\section{There were 12 podcasts/videocasts available. How many times did you make use of each one?}

One of the reported benefits of videocasting is that it can be watched more than once. Table 1 below shows the number of times students watched the videocasts and it is clear that most students used each videocast at least once (highlighted in grey).

Table 1: Number of times that students watched the videocasts

\begin{tabular}{|c|l|c|c|c|c|c|c|}
\hline \multirow{2}{*}{ \# } & \multicolumn{1}{|c|}{ Topic } & \multicolumn{5}{c|}{ Number of times videocasts were watched } \\
\cline { 3 - 8 } & & None (\%) & $\mathbf{1}(\%)$ & $\mathbf{2}(\%)$ & $\mathbf{3}(\%)$ & $\mathbf{4}(\%)$ & $\begin{array}{c}\mathbf{5} \text { or more } \\
\text { times (\%) }\end{array}$ \\
\hline 1 & Welcome to TAX2601 & 13.6 & 52.5 & 18.6 & 5.1 & 5.1 & 5.1 \\
\hline 2 & How to approach TAX2601 & 10.2 & 52.5 & 20.3 & 7.6 & 2.5 & 6.8 \\
\hline 3 & Taxable income framework & 8.8 & 40.4 & 24.6 & 9.6 & 6.1 & 10.5 \\
\hline 4 & Business income & 18.6 & 36.4 & 22.0 & 8.5 & 6.8 & 7.6 \\
\hline 5 & Prepaid expenses & 14.8 & 37.4 & 22.6 & 13.0 & 2.6 & 9.6 \\
\hline 6 & Introduction to assets & 18.1 & 39.7 & 13.8 & 11.2 & 5.2 & 12.1 \\
\hline 7 & $\begin{array}{l}\text { Capital allowances: SBC and } \\
\text { manufacturing }\end{array}$ & 8.7 & 33.0 & 19.1 & 13.0 & 4.3 & 21.7 \\
\hline
\end{tabular}




\begin{tabular}{|c|l|c|c|c|c|c|c|}
\hline \multirow{2}{*}{$\#$} & \multicolumn{1}{|c|}{ Topic } & \multicolumn{5}{c|}{ Number of times videocasts were watched } \\
\cline { 3 - 8 } & & None (\%) & $\mathbf{1}(\mathbf{\%})$ & $\mathbf{2}(\%)$ & $\mathbf{3}(\%)$ & $\mathbf{4}(\mathbf{\%})$ & $\begin{array}{c}\mathbf{5} \text { or more } \\
\text { times (\%) }\end{array}$ \\
\hline 8 & Capital allowances: buildings & 11.1 & 32.5 & 16.2 & 13.7 & 3.4 & 23.1 \\
\hline 9 & $\begin{array}{l}\text { Capital allowances: general wear } \\
\text { and tear }\end{array}$ & 10.9 & 30.3 & 20.2 & 15.1 & 4.2 & 19.3 \\
\hline 10 & $\begin{array}{l}\text { Asset recoupments and } \\
\text { scrapping allowances }\end{array}$ & 12.4 & 35.4 & 17.7 & 11.5 & 5.3 & 17.7 \\
\hline 11 & Introduction to capital gains tax & 13.9 & 33.0 & 18.3 & 13.0 & 3.5 & 18.3 \\
\hline 12 & Assignment 02 feedback & 21.6 & 33.6 & 21.6 & 9.5 & 2.6 & 11.2 \\
\hline
\end{tabular}

A substantial number of students watched videocasts number $7,8,10$ and 11 more than five times. Based on the lecturer's experience, these topics tend to be more difficult and the respondents clearly took advantage of the fact that the videocasts on these topics could be viewed repeatedly to master the content. This result is in line with the findings of McKinney, Dyck and Luber (2009), namely that podcasts can only be of value to the learners if they listened to the podcast several times.

The number of times that the videocasts are watched is influenced by when (during the study process) the student uses the videocast. If the student uses it after they have mastered the study unit (as almost a third of the respondents did) or as revision before the exam, then the probability is strong that the videocast will only be listened to once, as the student is not learning anything new but merely reinforcing what they already know. However, when the videocast is utilised before or during the study time (almost a third of the respondents used it in the latter way), then the student might be more inclined to listen to it again after the study unit is mastered as well as when revision is done.

\section{How did you generally use the videocasts, for example on your own, with study buddies, in a tutor class, and so forth?}

As expected, from the response on a previous question namely "On what device did you mostly download and/or watch the videocast", 95.9 per cent $(n=123)$ of the respondents used the videocasts on their own. Only 4.1 per cent of the respondents used the videocasts in a group setup (with their study partners). This is expected, as distance students are, by default, more disseminated across the world and they very rarely have the opportunity to study in groups. Most of the respondents reported that they are studying part-time, which makes participation in study groups more difficult.

Researchers have found that podcasts can spark social networking and collaborative learning if they are shared amongst learners (Dale 2007, 51). However, in a distance learning environment, it makes sense that students mostly study on their own and therefore watch the videocasts on their own, especially if they study part-time and only tend to their studies after hours. 


\section{Usefulness of videocasts}

The second research objective, namely to explore whether videocasts are useful to students, is addressed in the last few questions of the survey.

\section{Please give your opinion on the following statements regarding the use of videocasts:}

The respondents were requested to provide their opinion on ten statements regarding their experience with the use of the videocasts. A 5-point Likert scale was provided and respondents could indicate whether they strongly agree, agree, are neutral, disagree or strongly disagree with the statement provided. Some of the statements were duplicated (statements 2 and 3 ) or asked in an opposite way (statements 8 and 9) to test whether the respondents answer the related statements in a similar manner. As indicated by the percentages in the chart below, most of the students believe that the videocasts helped them in their studies.

\section{Statements regarding the use of the videocasts}

Strongly disagree, disagree and neutral $\quad$ Strongly agree and agree

10. I think the videocasts helped me to get better marks for the topics that were covered $(n=124)$

9. The videocasts wasted my study time $(n=123)$

8. The videocasts saved me time in studying the topic $(n=124)$

7. The content was not relevant to my needs as I already knew most of it $(n=123)$

6 . The content of the videocasts was useful to me $(n=125)$

5. The videocasts assisted me with learning about the topics $(n=123)$

4. I really enjoyed the videocasts $(n=120)$

3. The videocasts helped me focus on the module $(n=123)$

2. The videocasts helped me stay focused on the module $(n=124)$

1. The videocasts stimulated my interest in this subject $(n=125)$

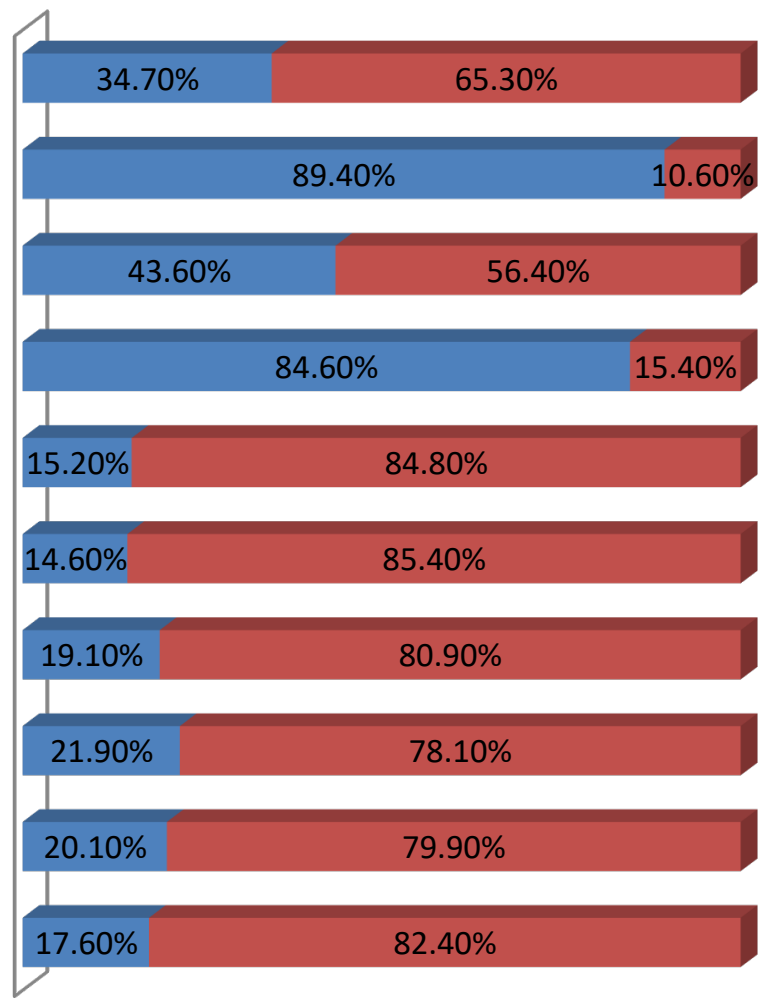

Graph 2: Student responses to statements regarding the use of videocasts 
The first four statements test (one to four) whether the videocasts had a motivational effect. Most students found it beneficial and this is most probably due to the use of a different medium other than text.

The next three statements determined whether the videocasts assisted the students in understanding the complex content of the subject. Most respondents consistently indicated that it helped them to gain a better understanding of difficult concepts and that the additional support was valuable.

The last three statements established whether the videocasts are useful in the respondents' opinion, based on their experience during the semester. A little over more than half of the respondents indicated that the videocasts saved them time during their study process $(56.4 \%)$ and the majority of respondents indicated that it did not waste their study time $(89,4 \%)$. This indicates that if respondents dedicate some of their valuable study time to using the videocasts, they will not be disappointed with the resource.

The last statement required a subjective view of the respondents, based on their perceptions. The result could not be compared to actual exam marks, since the respondents answered anonymously. It is clear, however, that many respondents $(65.3 \%, n=124)$ consider the videocasts very useful in aiding them to achieve a higher exam mark.

The previous discussion relates to the descriptive statistics. Several inferential statistical analyses were also performed. In order to determine the strength of a relationship between the two identified factors, namely usefulness and attention, the Pearson correlation coefficient was calculated. There is a strong positive correlation (statistically significant) between these two factors $(\mathrm{r}=0.696, p=0.000)$, which indicates that a higher level of usefulness will result in a higher level of attention and vice versa. Therefore, the inferential analysis examined whether there are differences between students' experience of use with reference to attention and usefulness and between demographics with reference to attention and usefulness. The differences with respect to these concepts were not statistically significant, but the trend in the mean ranks between the categories of location of access, age, first-time or repeater students, and full-time or part-time students are noteworthy and will be reported on in this study.

\section{Location of access}

To determine whether statistical significant differences exist between usefulness and attention and the students' experience of use, the Kruskal-Wallis test was used. The results indicate that there is no statistical significance between the locations where the students accessed the videocasts with respect to both factors $(p=0.358$ and $p=0.404)$. However, the mean ranks indicate that students who access the videocasts at a Unisa centre agree the most with the 
attention and usefulness of the videocasts (mean rank $=65.56$ for attention and 69.53 for usefulness), than those students who accessed it from work or home. This indicates that students who have to put in extra effort to obtain the videocasts by going to a location away from their home or work perceive themselves to receive more benefit from this resource.

Table 2: Test statistics for grouping variable: Location of access

\begin{tabular}{|l|c|c|}
\hline & Attention & Usefulness \\
\hline Chi-Square & 2.054 & 1.810 \\
\hline df & 2 & 2 \\
\hline Asymp. Sig. & .358 & .404 \\
\hline
\end{tabular}

Table 3: Mean ranks for grouping variable: Location of access

\begin{tabular}{|l|l|c|c|}
\hline \multirow{3}{*}{ Attention } & \multicolumn{1}{|c|}{ Ranks } & N & Mean Rank \\
\cline { 2 - 4 } & Home & 74 & 53.46 \\
\cline { 2 - 4 } & Work & 20 & 57.28 \\
\cline { 2 - 4 } & Unisa centre & 17 & 65.56 \\
\cline { 2 - 4 } & Total & $\mathbf{1 1 1}$ & \\
\hline Usefulness & Home & 80 & 57.75 \\
\cline { 2 - 4 } & Work & 21 & 60.40 \\
\cline { 2 - 4 } & Unisa centre & 18 & 69.53 \\
\cline { 2 - 4 } & Total & $\mathbf{1 1 9}$ & \\
\hline
\end{tabular}

\section{Age}

The Kruskal-Wallis test also indicated that there is no statistical significant difference between the two identified factors (usefulness and attention) and the demographic variable of the age group of the students. The mean ranks, however, highlight that students between 22 and 30 years of age value the attention feature of the videocasts most, while students between the age of 41 and 50 perceive the usefulness of the videocasts to be the most beneficial (mean rank $=$ 62.80 for attention and 66.17 for usefulness). This indicates that younger students require more motivation to focus their attention on studying, while older students (who may be more determined to complete their studies) receive more benefit from the videocasts by means of additional support with respect to technical content.

Table 4: Test statistics for grouping variable: Age

\begin{tabular}{|l|c|c|}
\hline & Attention & Usefulness \\
\hline Chi-Square & 3.767 & .842 \\
\hline $\mathrm{df}$ & 3 & 3 \\
\hline Asymp. Sig. & .288 & .839 \\
\hline
\end{tabular}




\section{First time/repeater students}

The t-test for independent groups was used to determine whether statistical significant differences exist between the experience of attention and usefulness of students registered for the first time and students repeating the module. A 5 per cent level of significance was applied and the t-test results indicate that no statistical significant differences $(p>0.4)$ exist. The mean values show that students who were repeating the module experienced more benefit from the videocasts in terms of attention and usefulness. A possible reason might be that students who had failed the module previously may be more inclined to utilise additional resources to assist them in gaining more knowledge than the previous round of studying.

\section{Full-time/part-time students}

The Mann-Whitney test indicated that there is no statistical significant difference, at the 5 per cent level of significance, between students studying full-time and students studying part-time with respect to attention and usefulness ( $p=0.631$ and $\mathrm{p}=0.595)$. However, the mean ranks indicate that full-time students tend to agree more that videocasts assist them with attention (mean rank $=62.12$ ) and usefulness (mean rank $=66.64)$ than the students studying part-time. The reason for this might be that students who study full-time have more dedicated study time in which they can make use of the additional resources like videocasts. Therefore, it assists them to focus on their studies and also adds value in terms of usefulness. Part-time students will usually be focused on their studies anyway (without any additional resources), as they know that they have limited time to cover the module content.

Table 5: Test statistics for grouping variable: full-time/part-time students

\begin{tabular}{|l|c|c|}
\hline & Attention & Usefulness \\
\hline Mann-Whitney U & 609.500 & 698.000 \\
\hline Wilcoxon W & 5862.500 & 6693.000 \\
\hline Z & -.480 & -.532 \\
\hline Asymp. Sig. (2-tailed) & .631 & .595 \\
\hline
\end{tabular}

The Pearson chi-square test of independence was applied to determine the association (relationship) between demographic variables and students' experience of use and this test revealed that there is no statistically significant relationship between these two variables.

\section{CONCLUSION}

This article provided an overview of how distance students use videocasts and how this resource is useful and supports their learning. The article argues for these tools to be conceived within 
an alternative paradigm of transaction distance, as mediated by seeing teaching and learning more as social phenomena in DE as opposed to physical or geographical (Moore 1983, 55).

In line with Saba, (2005), the value of this article is to locate teaching and learning within $\mathrm{DE}$ as a social system that has dynamic opportunities for cybernetic learning. As the student population entering higher education changes, along with the changes in technology, so teaching and facilitation methods need systemically to evolve to suit these changes (Francom, Ryan and Kariuki 2011, 51). This study showed that the use of videocasts in distance education is useful to students. What was disconcerting, but understandable within the missing picture of reconceiving of $\mathrm{DE}$ as a system, was the fact that many students did not make use of these resources. Lack of time was the biggest factor that kept students from using the videocasts. With respect to the use or non-use of videocasts, the overriding factor appears to be the fact that communication to students about the benefit of the resource requires attention. The non-use will require further interrogation in order to ascertain the best way to approach designing this resource.

The design principles for developing videocasts should be based on more complex systems requirements that are inherent to autonomy and structure more suited to DE students (Saba 2005, 268). Therefore, it should be socially determined around when the students make use of the videocasts during their study programme, and not the length of the recording, considering that cost did not seem to be a factor that was considered by students as a hindrance. The study revealed that videocasts were used mainly during focused study time while reading through the study unit or after reading the study unit, rather than "on the go". The design of the videocasts should therefore not incorporate too much basic or introductory information to the topic. The fact that videocasts covering more complex topics were watched more than the others indicates that lecturers should focus on areas where they know students struggle with the content. Videocasts should be designed in such a way that the objective of each videocast is clearly indicated to the students, for example - "watch this videocast before you read the study unit" or within a study unit - "watch videocast xxx before you continue".

There are a number of unanswered questions with regard to the use of videocasts and therefore continued interaction with the students making use of these resources will be required. The design and development of such resources is not a static one and lecturers can continually learn from the users in terms of design principles.

\section{REFERENCES}

Altbach, Philip G. 2012. A half-century of Indian higher education. Essays by Philip G. Altbach, ed. Pawan Agarwal. SAGE Publications. https://books.google.co.za/books?hl=en\&lr=\&id= mX0tBAAAQBAJ\&oi $=$ fnd\&pg $=$ PA9\&dq $=$ systemic + realities + Altbach\&ots $=q X O 4 E p 0 t L g \& s i g=$ 
$\mathrm{z} \_$_e8jtt5JWH6qib-kTNXuN4vK4\#v=onepage $\& \mathrm{q}=$ systemicrealities Altbach\& $\mathrm{f}=$ false.

Altbach, Philip G., Liz Reisberg and Laura E. Rumbley. 2009. Trends in global higher education: Tracking an academic revolution trends in global higher education. doi:10.1016/j.bse.2004.04.006.

Baker, Russell, Jeffery Harrison, Barry Thornton and Rhett Yates. 2008. An analysis of the effectiveness of podcasting as a supplemental instructional tool: A pilot study. College Teaching Methods and Styles Journal 4(3): 49-54.

Beldarrain, Yoany. 2006. Distance education trends: Integrating new technologies to foster student interaction and collaboration. Journal of Distance Education 27(2): 139-153. doi:10.1080/01587910600789498.

Berge, Zane L. 2013. Barriers to communication in distance education. Turkish Online Journal of Distance Education 14(1): 374-388. doi:10.17718/tojde.66881.

Bolliger, Doris U., Supawan Supanakorn and Christine Boggs. 2010. Impact of podcasting on student motivation in the online learning environment. Computers and Education 55(2): 714-722. Elsevier Ltd. doi:10.1016/j.compedu.2010.03.004.

Cebeci, Zeynel and Mehmet Tekdal. 2006. Using podcasts as audio learning objects. Learning 2: 4757. http://ijklo.org/Volume2/v2p047-057Cebeci.pdf.

Chan, Anthony and Catherine McLoughlin. 2006. Everyone's learning with podcasting: A Charles Sturt University experience. Ascilite Conference: Who's Learning? Whose Technology? no. 1990: 111120. http://www.ascilite.org.au/conferences/sydney06/proceeding/pdf_papers/p171.pdf

Conole, Gráinne. 2013. Designing for learning in an open world. New York: Springer. doi:10.1007/9781-4419-8517-0.

Dale, Crispin. 2007. Strategies for using podcasting to support student learning. Journal of Hospitality, Leisure, Sport \& Tourism Education 6(1): 49-57.

Daniel, John S. 1996. Mega-universities and knowledge media. Routledge, Taylor and Francis Group.

Davis, Fred D. 1993. User acceptance of information technology: System characteristics, user perceptions and behvioral impacts. International Journal of Man-Machine Studies 38: 475-487. https://ac.els-cdn.com/S0020737383710229/1-s2.0-S0020737383710229-main.pdf?.tid=2e57f 523-ddd8-4cba-bafd-803522729df5\&acdnat=1548325422_128c0fdd4d50bbbea21abb9fe $70977 \mathrm{~d} 1$

De Hart, Kerry, Yuraisha Chetty and Elizabeth Archer. 2015. Uptake of OER by staff in distance education in South Africa. International Review of Research in Open and Distance Learning 16(2): $18-45$.

Dennen, Vanessa P. and Jennifer B. Myers. 2010. Podcast pedagogy: Message design, motivation, and learning. In E-Learn: World Conference on E-Learning in Corporate, Government, Healthcare, and Higher Education, ed. J. Sanchez and K. Zhang, 43-49. Orlando, Florida: Association for the Advancement of Computing in Education (AACE). https://www.learntechlib.org/p/35508

Edirisingha, Palitha, David Hawkridge and John Fothergill. 2009. A renaissance of audio: Podcasting approaches for learning on campus and beyond. European Journal of Open, Distance and ELearning 1(June): 1-9.

Edirisingha, Palitha, Gilly Salmon and John C. Fothergill. 2007. Profcasting: A pilot study and guidelines for integrating podcasts in a blended learning environment, 127-137. http://hdl. handle.net $/ 2381 / 404$

Elias, Tanya. 2011. Universal instructional design principles for mobile learning. The International Review of Research in Open and Distance Learning 12(2): 143-156. doi:10.1007/978-1-44190585-7.

Elliot, Elizabeth, Sharron King and Sheila Scutter. 2009. To podcast or not to podcast? Pedagogical decision making in the use of new technologies. In 2009 UniServe Science Proceedings, 30-36.

Evans, Chris. 2008. The effectiveness of M-learning in the form of podcast revision lectures in higher education. Computers and Education 50(2): 491-498. doi:10.1016/ j.compedu.2007.09.016. 
Fernandez, Vicenc, Pep Simo and Jose M. Sallan. 2009. Podcasting: A new technological tool to facilitate good practice in higher education. Computers and Education 53(2): 385-392. Elsevier Ltd. doi:10.1016/j.compedu.2009.02.014.

Francom, Jeff, Thomas G. Ryan and Mumbi Kariuki. 2011. The effects of podcasting on college student achievement and attitude. Journal of the Research Center for Educational Technology 7(2).

Gattis, L. 2008. Getting started with instructional podcasting. Journal of the Academy of Business Education 9(4): 1-10. http://www.ncbi.nlm.nih.gov/entrez/query.fcgi?db =pubmed\&cmd= Retrieve\&dopt $=$ AbstractPlus\&list_uids $=6578207051259546773$ related:1YxL1XV8SlsJ

Gikas, Joanne and Michael M. Grant. 2013. Mobile computing devices in higher education: Student perspectives on learning with cellphones, smartphones and social media. Internet and Higher Education 19: 18-26. Elsevier Inc. doi:10.1016/j.iheduc.2013.06.002.

Huang, Yueh Min, Yen Hung Kuo, Yen Ting Lin and Shu Chen Cheng. 2008. Toward interactive mobile synchronous learning environment with context-awareness service. Computers and Education 51(3): 1205-1226. doi:10.1016/j.compedu.2007.11.009.

Kay, Robin H. 2012. Exploring the use of video podcasts in education: A comprehensive review of the literature. Computers in Human Behavior 28(3): 820-831. Elsevier Ltd. doi:10.1016/j.chb.2012.01.011.

Keegan, Desmond J. 2013. Foundations in disatance education. Third. Routledge, Taylor and Francis Group.

Khechine, H., S. Lakhal and D. Pascot. 2009. A comparative study on the effectiveness of podcasting in distance learning. In The Fourth International Conference on Internet and Web Applications and Services. ICIW 2009, 590-595. doi:10.1109/ICIW.2009.94.

Lee, Mark J. W. and Anthony Chan. 2007. Reducing the effects of isolation and promoting inclusivity for distance learners through podcasting. Turkish Online Journal of Distance Education 8(1): 85104.

Liebenberg, Hanlie and Dion van Zyl. 2015. Integrated report on the findings of research on students' experience with ICTs - Highlights of key findings. Pretoria, South Africa.

Lowenthal, Jeffrey N. 2010. Using mobile learning: Determinates impacting behavioral intention. American Journal of Distance Education 24(4): 195-206. doi:10.1080/08923647.2010.519947.

McKinney, Dani, Jennifer L. Dyck and Elise S. Luber. 2009. ITunes University and the classroom: Can podcasts replace professors? Computers and Education 52(3): 617-623. doi:10.1016/j.compedu.2008.11.004.

Meade, Oonagh, Dianne Bowskill and Joanne S. Lymn. 2009. Pharmacology as a foreign language: A preliminary evaluation of podcasting as a supplementary learning tool for non-medical prescribing students. BMC Medical Education 9: 74-86. doi:10.1186/1472-6920-9-74.

Moore, Michael Grahame. 1983. On a theory of independent study. In Distance Education: International Perspectives, ed. David Sewart, Desmond J. Keegan and Börje Holmberg. London: St Martin's Press.

Moore, Michael Grahame. 2013. Handbook of distance education. $3^{\text {rd }}$ Edition. New York, New York: Routledge, Taylor and Francis Group.

Moore, Michael Grahame and William Anderson. (Ed.). 2003. Handbook of distance Education. doi:10.1111/j.1467-8535.2004.00409_10.x.

Moore, Michael Grahame and Greg Kearsley. 2012. Distance education: A systems view of online learning. Wadsworth Cengage Learning. https://books.google.co.za/books?hl=en\&lr= $\& \mathrm{id}=\mathrm{dU} 8 \mathrm{KAAAAQBAJ} \& \mathrm{oi}=$ fnd $\& \mathrm{pg}=\mathrm{PR} 4 \& \mathrm{dq}=$ moore + kearsley $+2012+$ distance + education $+\mathrm{a}+$ systems+view\&ots=D2Xg_2Eqky\&sig=CcpFoTqpPT-ONSXuFadUUjOXI9o\#v=onepage\&q= moore kearsley 2012 distance education a systems view $\& \mathrm{f}=\mathrm{false}$

MyBroadband. 2013. 3GB mobile data for R100 - Students only. Mybroadband. https://mybroad band.co.za/news/broadband/82951-3gb-mobile-data-for-r100-students-only.html 
Prensky, Marc. 2001. Digital natives, digital immigrants Part 1. On the Horizon 9(5): 1-6. MCB UP Ltd. doi:10.1108/10748120110424816.

Saba, Farhad. 2005. Critical issues in distance education: A report from the United States. Distance Education 26(2): 255-272. doi:10.1080/01587910500168892.

Saba, Farhad. 2011. Distance education in the United States: Past, present, future. Educational Technology 51(6): 11-18.

Saba, Farhad. 2012. A systems approach to the future of distance education in colleges and universities: Research, development, and implementation. Continuing Higher Education Review 76: 30-37.

Saba, Farhad. 2013. Building the future: A theoretical perspecitve. In Handbook of distance education, ed. Michael Grahame Moore, 49-65. Routledge.

Saba, Farhad and Rick L. Shearer. 2018. Transactional distance and adaptive learning. Planning for the furture of higher education. Routledge, Taylor and Francis Group. doi:10.1080/08923647.2018.1477534.

Scutter, Sheila, Ieva Stupans, Tim Sawyer and Sharron King. 2010. How do students use podcasts to support learning? Australasian Journal of Educational Technology 26(2): 180-191. doi:10.1016/j.compgeo.2011.07.004.

Smillie, Shaun. 2016. SA's sky-high data costs. Times Live. http://www.timeslive.co.za/ thetimes/2016/09/20/SAs-sky-high-data-costs

Stefanski, Angela J., Amy Leitze and Veronica M. Fife-Demski. 2018. Preservice teacher sense-making while learning to teach reading as seen through computer-mediated discourse. Reading Horizons 57(1): 32-54. http://search.ebscohost.com/login.aspx?direct=true\&db=ehh\&AN=129148010\& site= $=$ ehost-live

Stöter, Joachim, Mark Bullen, Olaf Zawacki-Richter and Christine von Prümmer. 2014. From the back door into the mainstream: The characteristics of lifelong learners. In Online distance education: Towards a research agenda, ed. Olaf Zawacki-Richter and Terry Anderson, 421-457. AU Press. http://microblogging.infodocs.eu/wp-content/uploads/2014/07/Online_Distance_Education.pdf

Sutton-Brady, Catherine, Karen M. Scott, Lucy Taylor, Giuseppe Carabetta and Steve Clark. 2009. The value of using short-format podcasts to enhance learning and teaching. Research in Learning Technology 17(3): 219-232. doi:10.3402/rlt.v17i3.10878.

Taleb, Zahra and Amir Sohrabi. 2012. Learning on the move: The use of mobile technology to support learning for university students. Procedia - Social and Behavioral Sciences 69: 1102-1109. (Iceepsy). Elsevier B.V. doi:10.1016/j.sbspro.2012.12.038.

Traxler, John. 2010. Distance education and mobile learning: Catching up, taking stock. Distance Education 31(2): 129-138. doi:10.1080/01587919.2010.503362.

Tynan, Belinda and Stephen Colbran. 2006. Podcasting, student learning and expectations. Proceedings ASCILITE 2006: 23rd Annual Conference of the Australasian Society for Computers in Learning in Tertiary Education, no. 2002: 825-832. http://eprints.usq. edu.au/21168

University of South Africa. 2020. Facts and figures. https://www.unisa.ac.za/sites/corporate/default/ About/Facts-\&-figures

Van Zanten, Rob. 2008. The value of lecture podcasting for distance and on campus students. Ascilite Conference, 1066-1070. http://www.ascilite.org.au/conferences/melbourne08/procs/ vanzanten.pdf

Wang, Yi Shun, Ming Cheng Wu and Hsiu Yuan Wang. 2009. Investigating the determinants and age and gender differences in the acceptance of mobile learning. British Journal of Educational Technology 40(1): 92-118. doi:10.1111/j.1467-8535.2007.00809.x 